\title{
Trust and team coordination in critical situations
}

\author{
Adrian H. Pitariu ${ }^{1}$ \\ University of Toronto, Canada
}

\begin{abstract}
In this paper I explore the process of team coordination. I propose a model by which team coordination emerges as a function of team mental models and team trust. Furthermore, I introduce a hierarchical approach to team mental models, and propose a framework that provides a better understanding of team processes and opens new avenues of research in the area of team cognition. I conclude with implications for future research and practice.
\end{abstract}

Key words: team processes, team mental models, trust, coordination.

\begin{abstract}
Rezumat
Acest studiu explorează procesul coordonării echipelor. Se propune un model pe baza căruia coordonarea echipelor emerge ca o funcție a modelelor mentale ale echipei şi ale încrederii în echipă. De asemenea, se introduce o abordare ierarhică a modelelor mentale ale echipei şi se propune un cadru care furnizează o mai bună înțelegere a proceselor din cadrul echipei şi care deschide noi direcții de cercetare în domeniul cogniției în echipe. În concluzie, articolul prezintă implicații pentru cercetările viitoare şi pentru practică.
\end{abstract}

Cuvinte cheie: procese de echipă, modele mentale ale echipei, încredere, coordonare.

\section{Introduction}

Teams are in these days becoming a fundamental component of most organizations due to their increased flexibility, capacity to adapt under pressure, and ability to provide a quick and flexible response to external demands (Kozlowski \& Bell, 2003). Consequently, over the past three decades researchers have dedicated increasingly more time and effort to understanding teams and developing models of team effectiveness (e.g. McGrath, 1964; Hackman, 1983; Guzzo, 1984; Gladstein, 1984). Most of these models have a common trait in relying on an input-processoutput (I-P-O) framework proposed by McGrath (1964).

A particular type of team that plays a significant role in our lives is referred to by the literature as the action team (Sundstrom et al, 1990). Sundstrom and his colleagues describe

\footnotetext{
${ }^{1}$ Adresa de corespondență: adrian.pitariu@utoronto.ca
}

action and performing teams as being composed of members with highly specialized roles, who cooperate for brief periods of time, in order to complete a task that requires a close synchronization of individual team members' actions. Examples of such teams are flight crews, firefighters, emergency/rescue teams, military units and surgical teams. For these teams, working conditions such as task interdependence, time pressure and operating in a high risk environment make it imperative that team members interact and coordinate their actions effectively in order to avoid a potentially disastrous outcome.

While most models of team effectiveness acknowledge, either directly or indirectly, team coordination as being a key process for team effectiveness, the literature, however, lacks in empirical data regarding coordination mechanisms and factors that affect this particular team process (Kozlowski $\&$ Bell, 2003). One concept that emerged from the cognitive psychology literature (Rouse \& Morris, 1986) and that is often times linked to 
coordination, is the team mental model or shared mental model construct (Klimoski \& Mohammed, 1994; Cannon-Bowers \& Salas, 1992). Due to the equivalence of the two terms I will use in this paper team and shared mental models alternately. While current research findings do provide empirical evidence for the importance of shared mental models to team coordination (e.g. Marks et al, 2002), there is still much unexplained variance, leaving open the question regarding types of coordination mechanisms affected as well as conditions that facilitate or obstruct coordination behaviors and team performance.

The way Simons and Peterson (2000) defined trust suggests that team trust could be a part of a team mental model, or even a team mental model per se, which will affect a team's processes and performance. Team or intragroup trust refers to trust among team members, which, at the group level, has been described by Simons and Peterson (2000) as a generalized expectation among group members with regard to their benevolence, honesty and competence. The purpose of this study is to investigate the effect of team trust on coordination processes. By this means I seek to establish a stronger link between team mental models and team coordination and, thereby look at team level conditions that may increase a team's overall performance.

\section{Team coordination and Team Mental Models}

Coordination is a central concept to the functioning of any organization (Van de Ven, Delbecq \& Koenig, 1976). Malone \& Crowston (1991) define coordination as managing interdependencies between activities. While good coordination is said to almost never be noticed in day-to-day life, the contrary is true about poor coordination, which has notable and unwanted effects most of the time, state the same authors.

Team coordination is critical to team effectiveness especially when the teams are engaged in interdependent tasks (Kozlowski \& Bell, 2003). Task interdependence refers to the extent to which a team member's performance is dependent upon another's performance (van de Ven et al, 1976). With regard to coordination taxonomies there are two main streams. According to Zalesny et al (1995) coordination has four components: coordination of goals, activities/tasks, actors/team members, and of interdependencies. Goal coordination refers to the process of selection between a number of possible goals through processes such as decision making and communication. Activities or task coordination is about mapping goals to activities/tasks, which is done through task analysis and strategy development. Team member coordination involves the process of mapping activities to actors or task assignment. Lastly, coordination of interdependencies refers to the management of all possible interdependencies in a team, such as resource allocation, sequencing and synchronizing.

While the previous model takes a functional perspective on coordination, the literature also describes a more formal model which consists of two components: explicit coordination and implicit coordination (Entin \& Serfaty, 1999). Explicit coordination is related to existing work organization/procedures and explicit communication. Implicit coordination is a form argued to rely on the existence of shared mental models among team members regarding task and team work (CannonBowers \& Salas, 1992). For the purpose of the current investigation I will only look at implicit coordination processes.

Although direct and indirect empirical evidence of the effect of team coordination on team effectiveness is abundant in the literature (e.g. Brannick et al, 1993; Dirks, 1999; Marks et al, 2002; Marks \& Panzer, 2004), the effect sizes vary considerably. The differences in results may be due to differences in measures employed (e.g. expert raters assessing teams on behaviorally anchored rating scales versus self-administered questionnaires, or specific coordination processes vs. global measures). Another explanation for the differences in team effectiveness variance explained by coordination may be due to the fact that most studies do not clearly distinguish between implicit and explicit coordination. For example, Marks et al (2002) test a model in which shared mental models are an antecedent of coordination. However, when measuring coordination, they rely on expert raters assessing observable behavior, which is evidence of explicit coordination.

Implicit coordination is a form of coordination without overt communication, and relying on shared mental models. Mental models are defined as "knowledge organized in structured, meaningful patterns that are stored in memory" and allow individuals to understand the environment, make inferences, 
predictions and take appropriate action (Rouse \& Morris, 1986; Johnson-Laird, 1983). Shared mental models are characterized as structured information patterns that are stored in the memory and which provide a set of organized mutual expectations to team members (Klimoski \& Mohammed, 1994). CannonBowers and colleagues (1993) describe in detail how mental models can relate to team processes such as communication, coordination and compensatory behavior, which in turn have an influence on team effectiveness. They also bring into discussion the issue of multiple mental models that can exist at the same time and they describe four distinct categories: equipment model, task model, team interaction model, and team model. Furthermore, these metal models can be envisaged as models relative to the task and models relative to the team (Mathieu et al, 2000). It is the latter category that is of interest for this paper. Team interaction models can be described in terms of knowledge content as models about roles/responsibilities, information sources, interaction patterns, communication channels and role interdependencies. While team interaction models are procedural in nature, team models contain knowledge about teammates' knowledge, skills, abilities, preferences and tendencies (Cannon-Bowers et al, 1993). A clear distinction between the two types of models can be seen here in that team interaction models have unique object which is the team as a whole, whereas in team models each team member can be identified as a subunit of the team and thus the team models is a summation of those subunits.

Empirical evidence of the differential effects of these different types of mental models on coordination is limited. For example, Stout et al (1999) found that the existence of a shared mental model about information sources and interaction strategies resulted in improved coordinated team performance. Another recent study (Mathieu et al, 2000), while relying on the mental model types proposed by Cannon-Bowers and her colleagues, argue that "the operationalization of four different types of mental models becomes unwieldy in a single study" and end up using a task versus team mental model paradigm. Their study however makes an important point in proving that team mental models are an important contributor to team coordination. Consistent with these findings I propose the following:
Proposition 1a: The presence of mental models about the team members will have a positive effect on implicit team coordination.

Proposition 1b: The presence of mental models about team interaction will have a positive effect on implicit team coordination.

Theoretical models about team/group effectiveness relying on the input-processoutput framework (McGrath, 1964; Hackman, 1983; Gladstein, 1984) consider team member characteristics, such as KSAs, attitudes, personality, and motivation, as input variables and communication, interaction, decision making and conflict resolution as group processes and task characteristics as moderators of the effect of processes on team effectiveness. Obviously, in this case, we can treat variables that are in the input category as antecedents of group processes. We could think in an analogous way about shared mental models. Since in this case I am only looking at mental models about the teamwork, let us consider the case of team models and team interaction models. As I mentioned earlier, according to Cannon-Bowers et al (1993) team interaction or teamwork models are models about roles/responsibilities, information sources, interaction patterns, communication channels and role interdependencies. These are the models that will enable teams to "perceive, interpret and respond to dynamic environments in a synchronized, adaptive fashion" (Salas et al 2004) based on a common/compatible framework about teamwork.

Based on the I-P-O framework as well as previous empirical data there are a number of factors that will facilitate the development of teamwork models. Rentsch and Klimoski (2001) provide evidence for team member schema agreement being a mediator between team composition, membership acquisition mode and size, and team effectiveness. In another study Stout et al (1999) found evidence that activity planning facilitated the development of teamwork models. Furthermore, Marks et al (2002) showed that cross-training had a significant positive effect on shared mental models. In line with these arguments I propose that:

Proposition 2: Teamwork mental models will mediate the relationship between team mental models and team effectiveness. 


\section{Team Trust and Team Coordination}

Trust is a central concept in social life in general and organizational behavior in particular. The construct of trust has been widely researched thus far and its beneficial effect on individual behavior, interpersonal relations as well as team and organizational level outcomes has been established by a number of researchers (e.g. Dirks \& Ferrin, 2001, 2002; Simons \& Peterson, 2000). Trust develops through repeated social interaction. Trustworthiness of a trustee is the result of a trustor's perceptions of the trustee as being competent, acting benevolently and possessing integrity (Meyer, Davis \& Schoorman, 1995). Also, Deutsch (1958) included a motivational component in his definition of trust, and described trust as "the expectation that the occurrence of an event will lead to behavior which the individual perceives to have greater negative motivational consequences if the expectation is not confirmed than positive motivational consequences if it is confirmed." The classic example in this case is that of the babysitter, i.e. parents trust a babysitter with their child while they are enjoying a movie, expecting that nothing bad will happen. In this case the positive outcomes (spending an enjoyable evening) are by far outweighed by the potential negative consequences of the babysitter betraying the parents' trust and consequently something bad happening to the baby.

At the team level, trust has been described as an attitude or generalized expectation towards the collective shared by the group members (Simons \& Petersen, 2000; Korsgaard, Sapienza \& Brodt, 2003). For example, in the case of firefighters, during the process of extinguishing a fire each individual trusts the rest of the team to act in a synchronized manner such that his life will not be endangered. While the confirmation of this expectation will lead to the positive outcome of the firefighter and his team successfully completing another mission, the potential downside, if this expectation is not confirmed, could be of catastrophic consequences. Based on the definitions of Deutsch (1958), Meyer, Davis and Schoorman (1995), and Simons and Petersen (2000), I define trust as one's willingness to rely on the team's actions in a situation involving high risk and vulnerability, based on a set of positive expectations with regard to the team's actions.
Dirks \& Ferrin (2001) find that the direct effects of trust on workplace behaviors and performance outcomes are quite inconsistent throughout the literature and that just like other positive attitudes such as satisfaction and commitment the general thesis that a positive attitude will lead to greater performance is not supported by empirical data. Consequently they propose an alternative approach to trust research, where trust serves as a moderator for the effects of other work performance determinants. This approach relies on two assumptions: one is that trust affects an actor's assessment of another party's behavior with whom the actor is in an interdependent relationship, and the second is that trust affects an actor's interpretations of the other party's behaviors. If we put these statements in the context of mental models the moderation proposition of Dirks \& Ferrin (2001) could be restated. Since teamwork or team interaction mental models deal with perception and interpretation of environmental and team specific cues (Salas et al 2004) a logical conclusion is that these mental models will be affected by trust.

According to Cummings and Bromiley (1996) collective trust is "a common belief among a group of individuals that another individual or group a) makes good-faith efforts to behave in accordance with any commitments both explicit or implicit, (b) is honest in whatever negotiations preceded such commitments, and (c) does not take excessive advantage of another even when the opportunity is available." Along the same line of thinking Meyer, Davis and Schoorman (1995) specify trust as being a consequence of the trustor's attributions of ability, benevolence and integrity towards the trustee. Thus, in order for an actor (team member) to trust another party (team/teammate), the actor must rely on a set of existing information patterns about that other party, such as knowledge about skills, abilities, preferences and tendencies. This information is exactly what Cannon-Bowers et al (1993) described as team models, which will vary as a function of the individuals who comprise the team. As I proposed earlier team models are an antecedent of team interaction mental models, being that different perceptions about individual team members will lead to specific expectations about team behavior that is appropriate or effective in certain situations and the amount of risk that one can assume in his own actions. However, since the 
knowledge/information encrypted in these team models has been identified as typical antecedent of trust (Meyer et al, 1995) the main effect of this information is trust development. Trust, in this case, is an attitude towards the team and will act as a driver for the generation/production of team interaction models (see Figure 1). Considering these facts, I propose the following relationship:

Proposition 3: Team trust will mediate the relationship between mental models regarding the members of the team and mental models about teamwork.

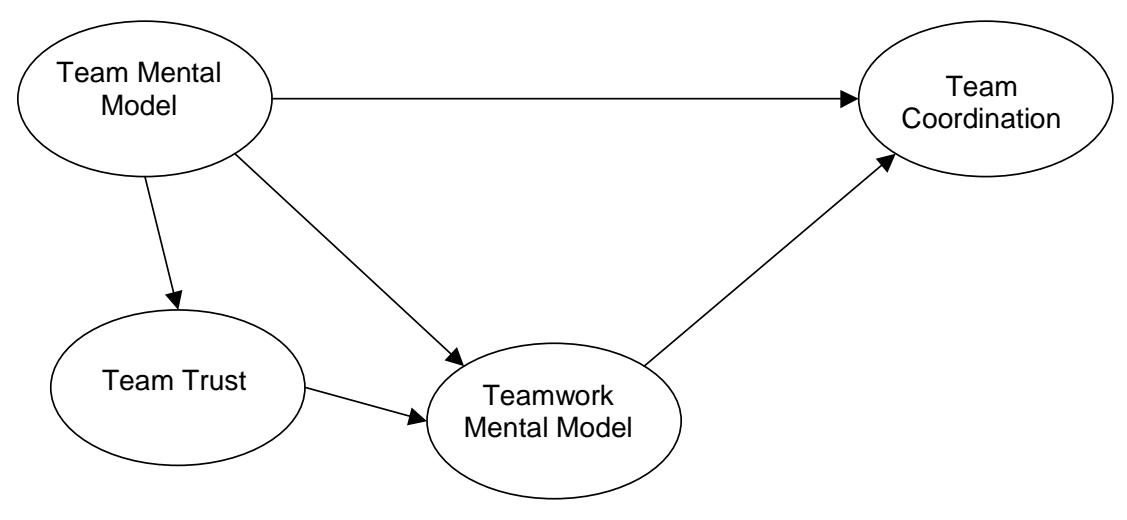

Figure 1. Overall model

\section{Implications and Future Directions}

The main focus of this paper is to provide a better understanding of the process of team coordination and its antecedents. In explaining team coordination I take a shared mental model approach, which is not new, since mental models have been proven to be antecedents of team coordination (Marks et al, 2002). The novelty in this approach, however, is in looking at the possibility of the different types of mental models interacting with each other and further influencing team level processes.

Because, up to this point, research involving shared mental models has focused on proving that shared mental models are an important antecedent of team processes, little attention has been given to differentiating between the different types of mental models as they were described by Cannon-Bowers, Salas and Converse (1993). One of the expressed reasons for doing so was the difficulty to operationalize different mental models in one study (Mathieu et al, 2000). Furthermore, even when empirical evidence for such distinction was found, the proposed theoretical models were tested under the assumption that the different mental models were independent from each other. By relaxing this assumption and entering trust as a mediating variable, I am introducing the possibility of dependence between shared mental models. Thus I am providing an alternative way of thinking about the role of shared mental models and their interplay in team processes.

From a practical perspective this approach suggests a prioritization in the team training sequence, such that training focusing on knowledge of team members' strengths and weaknesses (e.g. team-building interventions) precedes training on procedures. Furthermore team member selection and placement must be made with a careful consideration of the balance of KSAs in the team in order to maximize team potential.

In sum, by introducing a hierarchical approach to shared mental models within teams, the proposed framework provides a better understanding of team processes and opens new avenues of research in the area of team cognition.

\section{References}

Brannick, M.T., Roach, R.M., \& Salas, E. (1993). Understanding team performance: A multimethod study. Human Performance, 6, 287-308.

Cannon-Bowers, J.A., Salas, E., \& Converse, S.A. (1993). Shared mental models in expert team decision making. In N. J. Castellan Jr. (Ed.), Current issues in individual and group decision making (pp. 221-246). Hillsdale, NJ: Erlbaum. 
Cummings, L.L., \& Bromiley, P. (1996). The Organizational Trust Inventory (OTI): Development and Validation. In R.N. Kramer and T.R. Tyler (Eds.), Trust in Organizations. Thousand Oaks, CA: Sage.

Deutsch, M. (1958). Trust and suspicion. Journal of Conflict Resolution, 2, 265-297.

Dirks, K.T. (1999). The effects of interpersonal trust on work group performance. Journal of Applied Psychology, 84, 445-455.

Dirks, K.T., \& Ferrin, D.L. (2001). The role of trust in organizational settings. Organization Science, 12, 450-467.

Dirks, K.T., \& Ferrin, D.L. (2002). Trust in leadership: Meta-analytic findings and implications for research and practice. Journal of Applied Psychology, 87, 611-628.

Entin, E.E., \& Serfaty, D, (1999). Adaptive team coordination. Human factors, 41, 312-325.

Gladstein, D. (1984). A model of task group effectiveness. Administrative Science Quarterly, 29, 499-517.

Guzzo, R.A. (1986). Group decision making and group effectiveness in organizations. In P.S. Goodman (Ed.), Designing effective work groups. (pp.34-71). San Francisco: JosseyBass.

Hackman, J.R. (1983). A normative model of work team effectiveness. (Technical Repost No. 2). Research program on group effectiveness. New Haven, CT: Yale School of Organization and Management.

Johnson-Laird, P.N. (1983). Mental models: Towards a cognitive science of language, inference and consciousness. Cambridge, MA: Harvard University Press.

Klimoski, R.J., \& Mohammed, S. (1994). Team mental model: Construct or metaphor? Journal of Management, 20, 403-437.

Korsgaard, M.A., Brodt. S.E., \& Sapienza, H.J. (2003). Trust, identity and attachment: Promoting individuals' cooperation in groups In M. West, D. Tjosvold, and K. Smith (Eds.). International handbook of organizational teamwork and cooperative working (pp. 113130). West Sussex, UK: John Wiley \& Sons.

Kozlowski, S.W.J., \& Bell, B.S. (2003). Work groups and teams in organizations. In W.C. Borman, D.R. Ilgen, R.J. Klimoski (Eds.), Handbook of Psychology (vol.12): Industrial and Organizational Psychology (pp. 333-375). New York: Wiley.

Malone, T., \& Crowston, K. (1994). The interdisciplinary study of coordination. ACM Computing Surveys, 26, 87-119.

Marks, M.A., \& Panzer, F.J. (2004). The influence of team monitoring on team processes and performance. Human Performance, 17, 2541.

Marks, M.A., Sabella, M.J., Burke, C.S., \& Zaccaro, S.J. (2002). The impact of cross-training on team effectiveness. Journal of Applied Psychology, 87, 3-13.

Mathieu, J.E., Goodwin, G.F., Heffner, T.S., Salas, E., \& Cannon-Bowers, J.A. (2000). The influence of shared mental models on team process and performance. Journal of Applied Psychology, 85, 273-283.

Mayer, R.C., Davis, J.H., \& Schoorman, F.D. (1995). An integrative model of organizational trust. Academy of Management Review, 20, 709-734.

McGrath, J.E. (1964). Social psychology: A brief introduction. New York: Holt, Rinehart, \& Winston.

Rentsch, J.R., \& Klimoski, R.J. (2001). Why do 'great minds' think alike?: antecedents of team member schema agreement. Journal of Organizational Behavior, 22, 107-120.

Rouse, W.B., \& Morris, N.M. (1986). On looking into the black box: Prospects and limits in the search for mental models. Psychological Bulletin, 100, 349-363.

Salas, E., Stagl, K.C., \& Burke, C.S. (2004). 25 years of team effectiveness in organizations: Research themes and emerging needs. In C.L. Cooper, I.T. Robertson (Eds.), International Review of Industrial and Organizational Psychology (Vol.19, pp. 47-..). New York: John Wiley \& Sons.

Simons, T.L., \& Peterson, R.S. (2000). Task conflict and relationship conflict in top management teams: The pivotal role of intragroup trust. Journal of Applied Psychology, 85, 102-111.

Stout, R. J., Cannon-Bowers, J. A., Salas, E., \& Milanovich, D. M. (1999). Planning, shared mental models, and coordinated performance: An empirical link is established. Human Factors, 41, 61-71.

Sundstrom, E., DeMeuse, K.P., \& Futrell, D. (1990). Work teams: Applications and effectiveness. American Psychologist, 45, 120-133.

Van De Ven, A.H., Delbecq, A/L., \& Koenig, R. (1976). Determinants of coordination modes within organizations. American Sociological Review, 41, 32-338.

Zalesny, M.D., Salas, E., \& Prince, C. (1995). Conceptual and measurement issues in coordination: Implications for team behavior and performance. In G.R. Ferris (Ed.), Research in personnel and human resources management (Vol. 13, pp. 81-115). Greenwich, CT: JAI Press. 